\title{
Memória musical no diário do conselheiro Aires
}

\author{
Marcelo da Rocha Lima Diego
}

\begin{abstract}
RESUMO: Este ensaio busca intervir no debate sobre a presença da música no Memorial de Aires, de Machado de Assis, por meio de três argumentos. O primeiro é que as óperas a que o escritor pôde assistir devem ter tido maior impacto sobre a sua obra do que óperas a que ele não pôde assistir. O segundo é que o discurso e o repertório mobilizados pelo narrador-personagem desse romance devem ser tomados com tanta desconfiança quanto os mobilizados por outros narradores-personagens machadianos. E o terceiro é que a presença da música deve ser buscada no último romance do escritor antes no plano da sensação do que no do sentido.
\end{abstract}

PALAVRAS-CHAVE: Machado de Assis; Memorial de Aires; paisagem sonora; Richard Wagner; ópera e literatura.

ABSTRACT: This essay aims at analyzing the musical element in Machado de Assis's Counselor Ayres' Memorial, basing itself on three main arguments. First, that the operas which the author experienced first-hand had a larger influence in his work than the ones of which he heard a mere retelling. Secondly, that the discourse and repertoire depicted by the character-narrator Ayres must, as is the case with other Machadian narratives, be taken with a grain of salt. Finally, that in the author's final novel music makes itself more present as a sense than as a meaning.

KEYWORDS: Machado de Assis; Counselor Ayres' Memorial; soundscape; Richard Wagner; opera and literature. 
Na noite de 19 de setembro de 1883 , estreava no Teatro d. Pedro II, pela Companhia Italiana do empresário Ferrari, o drama lírico em três atos Lohengrin, primeira ópera de Richard Wagner encenada no Rio de Janeiro. A reação inicial dos diletantes da Corte à estética wagneriana, contudo, não foi das melhores: um artigo publicado no principal jornal da cidade, dois dias depois, revela que

Antes de cair o pano, haviam caído dois binóculos e um chapéu!

O grande dueto de amor (tem 24 páginas em partitura de piano e canto), onde se encontram peregrinas belezas, foi ouvido em silêncio, e em silêncio foi ouvido o resto da ópera. Eis o efeito que o Lohengrin produziu, anteontem, na maioria do nosso público. Tudo quanto se disser em contrário pode redundar em grande glória para o paladar artístico dos fluminenses, em grande crédito para a crítica nacional, mas é inteiramente faltar à verdade. ${ }^{1}$

A consagração do criador do Festival de Bayreuth junto ao público fluminense viria apenas nove anos mais tarde - não mais na Corte, e sim na Capital Federal -, com a estreia, em 30 de setembro de 1892, no Teatro Lírico (o mesmo e antigo Teatro d. Pedro II, na rua da Guarda Velha), do Tannhäuser, obra que cativou de imediato tanto a audiência leiga quanto a especializada. ${ }^{2}$

Embora as demais óperas do compositor tenham tido suas premières às margens da Guanabara já portas adentro do século xx, ${ }^{3}$ foi ainda nas décadas de 1880 e 1890 - com as estreias de Lohengrin e Tannhäuser e com a consequente disseminação das adaptações para piano, para orquestra sinfônica e de câmara desses e de outros títulos do compositor - que Wagner passou a fazer parte do repertório das casas de ópera, das

1. JORNAL DO COMÉrcio, Rio de Janeiro, 21 set. 1883, p. 1. Todos os periódicos a que se faz referência aqui foram consultados por meio da Hemeroteca Digital Brasileira, acessível em <http://bndigital.bn.gov.br/ hemeroteca-digital/>. (Acesso: abril de 2018).

2. Vincenzo Cernicchiaro credita o sucesso do Tannhäuser no Rio de Janeiro, em 1892, à sua forma "italiana”, ou seja, ao seu caráter lírico acentuado, próximo da tradição do bel canto, que tanto agradava aos diletantes fluminenses. Cf. CERnicchiaro, Vincenzo. Storia della Musica nel Brasile: dai tempi coloniali sino ai nostri giorni (1549-1925). Milano: Fratelli Riccioni, 1926, p. 259.

3. Die Meistersinger von Nürnberg estreou na cidade em 1905; Tristan und Isolde, em 1910; Parsifal e Die Walküre, em 1913; e a tetralogia Der Ring des Nibelungen completa, em 1922, durante as comemorações do centenário da independência. 
salas de concerto e dos salões aristocráticos do Rio de Janeiro. A sua música constitui, assim, uma camada significativa da paisagem sonora ${ }^{4}$ sobre a qual se deu a passagem do Império para a República, no Brasil. Não por acaso, em duas crônicas da série "A Semana", de 1892 e 1893, Machado de Assis refere-se às estreias wagnerianas de 1883 e 1892 no interior de uma reflexão sobre a passagem do tempo e as transformações do espaço ao seu redor - em outras palavras, como desdobramento da tópica clássica "Tempora mutantur".

No terreno da ficção, a narrativa machadiana que estabelece diálogo mais íntimo com a lírica wagneriana é o Memorial de Aires, de 1908. A música, de maneira geral, e a ópera, em particular, ocupam lugar central no último romance de Machado de Assis, tanto no que diz respeito ao conteúdo da narrativa quanto no que se refere à forma da narração. Como se sabe, o Memorial é um romance disfarçado de diário, em que o conselheiro Aires, ao mesmo tempo narrador e personagem, relata sua convivência próxima com o casal Aguiar e seus dois "filhos postiços": Fidélia, a jovem "viúva Noronha", e Tristão (que os Aguiares ajudaram a criar, quando criança, e depois seguiu com os pais para Portugal, de onde retornou para "liquidar alguns negócios", no recorte de dois anos - 1888 e 1889 - em que se situa a narrativa), os quais por fim se casam e se mudam para Lisboa.

Fidélia e seu primeiro marido, Eduardo, ambos naturais da cidade de Paraíba do Sul, no interior fluminense, onde suas famílias eram rivais, haviam-se conhecido na Corte: "A primeira vez que ele a viu foi das torrinhas do Teatro Lírico, onde estava com outros estudantes; viu-a à frente de um camarote, ao pé da tia. Tornou a vê-la, foi visto por ela, e acabaram namorados um do outro". Exímia pianista, Fidélia abandonara a música, após a morte do marido; e foi somente devido à insistência e ao estímulo de

4. A expressão "paisagem sonora" (ou, originalmente, soundscape) ganhou foro de conceito a partir da década de 1970, em função do trabalho do maestro e professor canadense Murray Schafer, um dos fundadores do campo teórico dos Estudos Sonoros, ou Sound Studies. Refere-se, de maneira geral, a uma forma de cartografia de um tempo e lugar que leva em conta não os objetos que podem ser vistos, e sim os eventos que podem ser ouvidos. Cf. sCHAfER, Murray. The Soundscape: Our Sonic Environment and the Tunning of the World. Rochester, vT: Destiny Books, 1993.

5. GAZETA DE Notícias, Rio de Janeiro, 2 out. 1892 (sobre o Tannhäuser) e 3 set. 1893 (sobre Lohengrin).

6. Memorial de Aires, 10 fev. 1888. Todas as remissões à ficção de Machado de Assis são feitas, aqui, a partir da edição eletrônica em hipertexto de Marta de Senna, acessível em <http://machadodeassis.net/> (acessos em abril de 2018). 
Tristão, também ele virtuose ao piano, que ela voltou, pouco a pouco, a praticar o instrumento, na casa do tio (o desembargador Campos), onde vivia, e na dos Aguiares. A "ressurreição" musical de Fidélia é assunto da entrada de 31 de agosto de 1888 do diário do Conselheiro: na reunião em casa dos Aguiares, à véspera, Tristão tocara um trecho de Mozart, e Fidélia, um de Schumann. Antonio Candido, em um ensaio curto, porém profundamente lírico, associa o renascimento musical da personagem ao seu renascimento amoroso:

No Memorial de Aires ela [a música] entra para manifestar o amor nascente entre Fidélia (nome beethoveniano) e Tristão (nome wagneriano). Por entre as linhas sóbrias, flui como símbolo da paixão primaveril e crescente, marcando o retorno da bela viúva às emoções da vida e o enlevo do moço, que por causa de Fidélia deixa as ambições políticas. Graças à técnica progressiva do diário, disfarçando a onisciência do romancista, o narrador ignora em teoria o que se passará na entrada seguinte. E esta candura de presente do indicativo o deixa tecer com verossimilhança a força premonitória da música. Quando o conselheiro abre os olhos, o casal de jovens já está em pleno diálogo de reticências, que para Brás Cubas era o de Adão e Eva. ${ }^{7}$

Tocado pelas belas performances oferecidas por Fidélia e Tristão, o conselheiro revela ter sido a música, sempre, uma das suas inclinações, "e, se não fosse temer o poético e acaso o patético, diria que é hoje uma das saudades". ${ }^{8}$ Em outra passagem, novamente falando de si, vale-se de uma citação musical: à diferença do pai e do sogro de Fidélia, inimigos políticos, não odeia "nada nem ninguém: perdono a tutti, como na ópera". ${ }^{9}$ É também ele, o conselheiro, quem sugere a relação entre o nome de Fidélia e a ópera de Beethoven: "Terá sido dado à filha do barão, como a forma feminina de Fidélio, em homenagem a Beethoven?”. ${ }^{10}$ E é ainda ele, Aires, quem leva Tristão a

7. CANDIDO, Antonio. “A música e a música”. In: O observador literário. 3 ed., rev. e ampl. Rio de Janeiro: Ouro sobre Azul, 2004, p. 27.

8. Memorial de Aires, 31 ago. 1888.

9. Memorial de Aires, 14 jan.1888. Trata-se de uma citação do Ernani (1843), de Verdi.

10. Memorial de Aires, 11 fev. 1888. A sugestão do conselheiro parece tanto mais forçada quando se constata haver outras fontes, mais próximas, para o nome da filha do barão de Santa Pia. O mesmo rio Paraíba do Sul, que corta e dá nome à cidade natal de Fidélia, também corta, duzentos quilômetros ao norte, a cidade de São Fidélis; esta foi um importante centro agrícola, durante os séculos XVIII e XIX, 
Wagner: "Aniversário da batalha de Sedan. Talvez vá à casa do desembargador pedir a Fidélia que, em comemoração da vitória prussiana, nos dê um pedaço de Wagner"." "Nem Wagner, nem outro. Tristão estava lá e deu-nos um trecho de Tannhäuser, mas a viúva Noronha recusou o pedido"."

Desde o aparecimento do Memorial de Aires, a crítica mostrou-se atenta às ressonâncias wagnerianas na última narrativa longa machadiana. Araripe Júnior, por exemplo, refere-se ao diário do conselheiro como um "suavíssimo poema wagneriano da saudade".13 Todavia, foi Raymond Sayers, na década de 1960, quem primeiro examinou em detalhe o impacto das criações do compositor sobre as do escritor, no artigo "A caminho de Bayreuth:

tendo dado origem a dois titulares do Império: o barão de São Fidélis e o barão de Vila-Flor. Chama-se Fidélio, ainda, uma personagem de "Os segredos da Babilônia", segunda parte de O janota (tradução livre de Les gandins), romance-folhetim de Pierre Alexis, o célebre (e autodenominado) visconde de Ponson du Terrail, publicado em Paris, em 1861, e, no Rio de Janeiro, entre 1871 e 1872, no rodapé do Diário de Notícias. Por fim, a única ópera do maestro Francisco Manoel da Silva, sobre libreto de Manoel de Araújo Porto Alegre, O prestígio da lei, de 1859, tem como uma de suas principais personagens um sujeito de nome Fidélio; o libreto foi publicado como folhetim, entre maio e junho daquele ano, pela Marmota, de Paula Brito, veículo do qual Machado de Assis era colaborador e amigo. Aires também declara não conhecer nenhuma "Santa Pia", que justificasse o nome da propriedade e, consequentemente, do baronato do pai de Fidélia, indo a Dante, em busca de referência a alguma "Pia"; ora, se ele aceita que "Fidélia" seja homenagem, em forma feminina, a "Fidélio", por que não poderia ser "Pia" alusão, em forma feminina, a "Pio" - no caso, a Pio IX, segundo papa mais longevo da história (atrás apenas de São Pedro), que esteve à frente da Igreja Católica de 1846 a 1878 (logo, durante a maior parte do Segundo Reinado brasileiro), responsável pelo primeiro Concílio Vaticano? A propósito de onomástica, é oportuno observar que o nome "Tristão", que a crítica tão imediatamente associou ao amante de Isolda, na legenda medieval e na ópera de Wagner, não era de todo estranho aos costumes portugueses, como prova a existência de importantes personagens da história lusitana, como os navegadores seiscentistas Tristão da Cunha e Tristão Teixeira Vaz. A origem céltica desse nome causa ainda menos estranheza, ao se remontar a origem da família de Tristão (o do Memorial) a Guimarães - sua mãe, comadre de d. Carmo, chama-se Luíza Guimarães -, bastião da resistência ibérica (cuja matriz era céltica) à conquista romana.

11. Memorial de Aires, 2 set. 1888.

12. Memorial de Aires, 3 set. 1888 .

13. Apud GLEDson, John. “The Last Betrayal of Machado de Assis: Memorial de Aires”. Portuguese Studies 1, Londres, 1985. Para um panorama da recepção crítica à época da publicação do romance, que deu a nota geral pela qual ele foi lido, por mais de meio século, cf. Guimarães, Hélio de Seixas. Os leitores de Machado de Assis: o romance machadiano e o público de literatura no século 19. São Paulo: Nankin; Edusp, 2004, pp. 406-38. 
a música na obra de Machado de Assis"; como o título já dá a entender, o ensaísta enxerga Wagner como um ponto de chegada no processo de apuro do gosto musical de Machado e de incorporação de elementos musicais à sua escrita. Foi Sayers, depois de traçar um panorama da presença da ópera na obra de ficção e na crônica machadianas e de descrever a aproximação gradual de Machado a Wagner, quem primeiro desenvolveu a hipótese do Tristan und Isolde (doravante, referido apenas como Tristan) como subtexto do Memorial. Comparando o enredo do romance ao da ópera, ele conclui: "Há tantos elementos no Memorial sugestivos da ópera que seria difícil não acreditar que Machado não só estivesse escrevendo sob influência de Wagner, mas também estivesse procurando compor em termos da realidade carioca uma refundição da ópera quase tão complexa como o original"'14

Sayers observa, ainda, que Artur Napoleão, pertencente ao círculo íntimo de relações do escritor, acompanhara de perto as estreias wagnerianas, tendo assistido ao Ring des Nibelungen em 1875, e pode ter sido um dos primeiros a discutir Wagner com Machado. ${ }^{15}$ Além disso,

Embora Tristan não fosse ouvido até depois da morte de Machado, podemos supor que Nepomuceno, Francisco Braga ou Leopoldo Miguez terão levado a partitura para o seu conhecimento, e que também, através de artigos, conversações, versões instrumentais e até composições imitativas, ele terá se familiarizado tanto com a ópera que não seria inexato afirmar que o Memorial pode ser o Tristan und Isolde de Machado. ${ }^{16}$

Na década de 1980, John Gledson retornou a essa hipótese, no ensaio "The last betrayal of Machado de Assis: Memorial de Aires" ${ }^{17}$ Em um primeiro momento, o crítico inglês nota certo esteticismo que permearia as personagens do romance: no que diz respeito a Fidélia e Tristão, a pintura e a música são instrumentos da corte que o rapaz faz à moça; quanto a Aires,

14. SAYERs, Raymond. "A caminho de Bayreuth: a música na obra de Machado de Assis". Revista Hispánica Moderna, vol. 34, n. 3, 1968, p. 787 .

15. Idem, p. 779

16. Idem, p. 787 .

17. Publicado originalmente em inglês, em 1985, já no ano seguinte o texto apareceu em português, como um capítulo (intitulado "Memorial de Aires") do volume: GLedson, John. Machado de Assis: ficção e história. Tradução de Sônia Coutinho. Rio de Janeiro: Paz e Terra, 1986. 
Uma das suas principais tendências [...] é seu esteticismo. Um entusiasmo verdadeiro irrompe em meio ao costumeiro tom de ceticismo melancólico, quando Fidélia e Tristão tocam o piano [...]; e já vimos que o "prazer estético" é uma das categorias favoritas para explicar sua atração por Fidélia. ${ }^{18}$

Em seguida, Gledson justapõe a trama do romance à da ópera e afirma:

As analogias com nossa história são claras, mesmo sendo o tom emocional muito diferente. O dilema de Isolda entre a lealdade ao seu cavaleiro morto e o amor inconsciente por Tristão encontra o mais óbvio paralelo na lealdade de Fidélia à memória do marido e o (inconsciente?) amor de Tristão; certamente, este paralelo aponta para o que estou quase inclinado a tomar como um "fato" inconteste, dentro da ficção romanesca: os dois enamorados encontraram-se antes, em Lisboa (exatamente como Tristão e Isolda encontraram-se antes, na Irlanda). Não é preciso concluir que Tristão assassinou Eduardo, marido de Fidélia, embora isto pudesse acrescentar novas e deliciosas profundidades de maldade calculada a este "idílio"."

Em nota de rodapé, Gledson comenta que, enquanto de acordo com algumas fontes Tristão e Isolda se teriam apaixonado a bordo do navio, rumo à Cornualha, em função de uma poção mágica, na ópera de Wagner o relacionamento entre os dois é anterior à poção, remontando ao primeiro encontro entre a princesa e o guerreiro, na Irlanda. $\mathrm{O}$ crítico não deixa de notar que deve ter agradado a Machado ter sido essa a variante da lenda medieval escolhida por Wagner, uma vez que ela privilegia o conflito interior, e não as circunstâncias acessórias.

Sem embargo, os paralelos desenhados por Gledson (por sobre o tracejado de Sayers) entre o romance e a ópera não são, rigorosamente, paralelos. Em primeiro lugar, porque ele não compara o enredo do Memorial ao enredo de Tristan, e sim à sequência de acontecimentos que antecede à ação de Tristan, narrada por Isolda (em uma espécie de flashback), no Ato I, Cena $3 .{ }^{20} \mathrm{O}$ dilema de Isolda a que o crítico se refere, portanto,

18. GLEDSON, John. Op. cit., p. 228.

19. Idem, p. 246.

20. Gledson parece suspeitar de que essa objeção poderia ser feita, quando diz: "Se pareço dar pouca importância aos dois atos finais não é porque seja cego (ou surdo) à sua intensa beleza. Mas acredito que sejam 
pertence ao passado da ação, não tendo lugar na cena da ópera, enquanto o dilema de Fidélia a que ele alude - se de todo existe, como se verá a seguir - tem lugar na cena do romance. Quanto ao que de fato acontece durante a ópera - a voragem do desejo a que se entregam Tristão e Isolda $-{ }^{21}$ nenhum paralelo é traçado com o que acontece durante o romance. Em segundo lugar, o paralelo entre as duas obras tem como efeito o alçamento da relação entre Tristão e Fidélia a tema central do romance, uma vez que é eminentemente da relação entre Tristão e Isolda que trata a ópera; tal gesto, entretanto, joga para as bordas o que de direito pertence ao núcleo do Memorial: os dramas do casal Aguiar e do próprio Aires. ${ }^{22}$

secundários para o nosso objetivo - e o de Machado: é impossível que ele os tivesse escutado e improvável que este mais inteligente dos antirromânticos fosse simpatizar com sua autocomplacência e intensidade emocional. Muito mais importante é o enredo que acabamos de contar e que está contido, na maior parte, no primeiro ato da ópera" (Idem, pp. 245-6). Sua linha argumentativa, entretanto, revela-se problemática: ao dizer que os atos II e III são secundários aos seus propósitos e aos de Machado, ele parte da conclusão para a premissa, da hipótese para a análise, descartando parte significativa da materialidade textual da ópera; e ao desprezar o possível impacto dos dois últimos atos sobre Machado, por serem demasiado emotivos e autoindulgentes, parece ignorar que esses traços se mostram presentes já no primeiro ato.

21. É consenso, entre os comentadores, que o tema principal de Tristan und Isolde é a convergência da pulsão de vida e da pulsão de morte para a dimensão do desejo, tema que se manifesta de forma explícita na ária final de Isolda, conhecida como "Liebestod", ou "Amada morte". Para uma revisão crítica do assunto e uma fina leitura da ópera em tal chave, cf. Hutcheon, Linda; Hutcheon, Michael. "Death Drive: Eros and Thanatos in Wagner's Tristan und Isolde”. Cambridge Opera Journal 11.3, New York, 1999, pp. 267-94.

22. Assim como John Gledson, a partir do diálogo do Memorial com Tristan, remontou o enredo do romance de modo a dar a ver um casal Tristão-Fidélia frio e calculista, que trairia os "pais postiços", Luiz Roncari, a partir do diálogo do diário do conselheiro com o Fausto - a obra literária de Goethe, mas também o drama lírico de Gounod -, converteu Aguiar e Carmo em um casal vampiresco, que em função dos próprios interesses se interporia às ambições naturais dos "filhos postiços". Para esse crítico, Aires desempenharia, nessa trama, o papel de um "bom diabo", inverso ao de Mefistófeles - seu trabalho não seria o de perder, mas o de salvar Fidélia: "Se havia algo a ser feito para o bem de Fidélia, era salvá-la da teia de relações que a enredavam, tricotada pelas mãos caprichosas de dona Carmo e Aguiar. Eram estes que, como duas aranhas feiticeiras, construíam um círculo familiar pegajoso, um ninho de afetos que restringia a perspectiva de um destino a uma rotina de visitas, chás, conversinhas cordiais e cuidados com a própria vida e a alheia, que secavam o sujeito e o tolhiam de uma vida mais ampla, artística ou política. É esse inferno que Aires descreve e, quando se decide à ação, inverte as funções do diabo: seu papel passará a ser então o de salvador da alma de Fidélia daquele 'idílio' fantasioso, em que ela poderia se perder" (RONCARI, Luiz. "O bom diabo e a marinha de Fidélia”. In: O cão do sertão: 
Já nos anos 2000, coube a Pedro Meira Monteiro a retomada da discussão sobre o diálogo que o último romance de Machado de Assis estabelece com o repertório lírico. Seu ponto de partida - o Fidelio de Beethoven - é distinto do de Gledson, bem como sua compreensão do fenômeno da intertextualidade na ficção machadiana. Enquanto para o crítico inglês a alusão põe em destaque uma semelhança, para o brasileiro ela dá a ver uma diferença; enquanto um compara, o outro contrasta. Acompanhem-se alguns passos da reflexão de Monteiro:

O nome Fidélia é uma alusão evidente ao problema da fidelidade, embora marque também uma intricada relação intertextual com a ópera de Beethoven, na qual Fidélio é a máscara com que a fiel Leonora vai buscar o marido sequestrado. No entrecho romântico da ópera, Leonora sustenta a máscara da lealdade porque sabe que o marido está vivo, no fundo de um calabouço, esperando que a doce esposa o resgate. [... J Já no caso do romance de Machado de Assis, o marido de Fidélia está morto desde o início da trama. Mas se o esteio da fidelidade é raptado já de início, que fazer da máscara da fidelidade, se não há mais um marido a resgatar?³

Convém então refletir sobre como o entrecho e a música do Fidélio podem ter entrado, meio às avessas, no universo composicional do Memorial de Aires. Insisto numa ausência inevitável aqui - a música [...] - porque penso que o enlace do canto está no centro da cena do Memorial [...], embora saibamos que a fidelidade não é, ali, mais que a máscara a ocultar o real desejo da jovem, que supomos ("suposição" que devemos ao narrador) desejosa de abandonar o primeiro marido, por saber que ele não se esconde mais em canto algum. No Memorial de Aires, tudo já se inicia, muito placidamente, num cemitério. ${ }^{24}$

literatura e engajamento. São Paulo: Editora Unesp, 2007, pp. 167-8). Para a salvação desse "universo mesquinho", os únicos caminhos que possibilitariam aos filhos postiços "vislumbrar um mundo maior: o das realizações humanas e espirituais que permitem o verdadeiro florescimento individual" seriam o da arte e o da política, justamente os que seguem, respectivamente, Fidélia - com a música e a pintura - e Tristão - com a cadeira de deputado em Portugal (Idem, p. 177). Reconhecendo a originalidade desses dois percursos interpretativos, a presente leitura propõe que a malícia, no Memorial, não parte do velho casal Aguiar, nem do jovem casal Guimarães - e sim do solitário e extemporâneo Aires.

23. MONTEiro, Pedro Meira. "O outono da escrita: as últimas páginas de Machado de Assis e a promessa não cumprida do Brasil”. Novos Estudos Cebrap, vol. 35, n. 2, São Paulo, 2016, p. 235.

24. Idem. "Oui, mais il faut parier: fidelidade e dúvida no Memorial de Aires". Estudos Avançados, vol. 22, 
Há uma fantástica série de triângulos que dão movimento à trama e ao canto, mas o que vale ressaltar aqui é a apoteose da ópera, que recende a uma aposta iluminista na revelação plena de todos os valores mais caros à criatura humana: a fidelidade, a esperança, a transparência, a honestidade, a clareza, o amor. Enfim, todos os elementos que, um a um, a trama machadiana põe em suspenso, e sob suspeita..$^{25}$

A esta altura, é oportuno recordar um alerta metodológico feita por Gledson. O professor de Liverpool propõe que se leia o Memorial de Aires do mesmo modo que se lê Dom Casmurro - pelo menos, desde que se começou a lê-lo "com o pé atrás" -, ${ }^{26} \mathrm{ou}$ seja, a contrapelo do narrador. ${ }^{27}$ Também Aires, como Bento Santiago, escreve com uma

n. 64, São Paulo, Instituto de Estudos Avançados da Universidade de São Paulo, 2008, p. 307.

25. Idem. "O futuro abolido: anotações sobre o tempo no Memorial de Aires". Machado de Assis em linha, 1, Rio de Janeiro, Fundação Casa de Rui Barbosa, 2008, p. 46. Grifo do autor.

26. Helen Caldwell, na década de 1960, foi quem primeiro colocou sob suspeita o narrador de Dom Casmurro, ao revelar o interesse desse narrador-personagem em demonstrar a suposta culpa de Capitu. Por essa razão, o crítico português Abel Barros Baptista, na década de 1990, referiu-se a um "legado de Caldwell, ou paradigma do pé-atrás" como a tradição crítica que, na esteira da intérprete americana, dedicou-se a remontar o enredo do romance, a partir da detecção do lugar de fala comprometido do narrador (Cf. BAPTISTA, Abel Barros. "O legado de Caldwell, ou o paradigma do pé-atrás". Santa Barbra Portuguese Studies, 1, Santa Barbara, 1994, pp. 145-77). De modo semelhante, no caso do Memorial de Aires, seria possível aludir a um "legado de Paes", uma vez que foi José Paulo Paes, nos anos 1970, quem primeiro chamou atenção para as tensões e para o jogo de interesses que jazem sob o suposto idílio narrado no diário do conselheiro (Cf. PAEs, José Paulo. "Um aprendiz de morto". Revista de Cultura Vozes 7, Petrópolis, 1976, pp. 13-28; In: PAEs, José Paulo. Gregos \& baianos: ensaios. São Paulo: Brasiliense, 1985, pp. 13-36), desfazendo a imagem do Memorial como, na descrição de Marta de Senna (que, em seguida, a desmonta), "um livro de abrandamento, a reconciliação de Machado com a existência, uma narrativa em que as personagens são todas boas criaturas, ninguém é mau, todos têm boas maneiras e boas intenções, salvo a maledicente d. Cesária e seu inexpressivo marido" (sENnA, Marta de. Alusão e zombaria: citações e referências na ficção de Machado de Assis. 2 ed. rev. e aum. Rio de Janeiro: Edições Casa de Rui Barbosa, 2008, p. 97).

27. "É muito possível - e acredito que seja necessário - tratar a relação entre narrador e enredo, em Memorial de Aires, da mesma maneira como deve ser tratada - e tem sido - em Dom Casmurro. Ou seja, como resultado de uma saudável desconfiança em relação ao narrador, devemos ser capazes de reelaborar o enredo, e reconstruir outro diferente daquele que Aires nos conta. Fazendo isso, esse enredo se torna muito mais poderoso e significativo, como visão da realidade social e histórica, do que o idílio que alguns críticos consideraram um sintoma da reconciliação de Machado com a vida." (GLEDSON, John. Op. cit., p. 229). 
finalidade, obedecendo à sua agenda pessoal; também ele é imaginativo, digressivo, manipulador e monopoliza o discurso; também ele dá voz a um gênero, uma raça, uma classe particulares; e também ele está comprometido com uma representação específica de si mesmo e daqueles que o cercam. Desconstruindo a sua retórica - ou, ao menos, pondo a sua retórica sob suspeita -, é possível, praticamente, reconstruir uma nova trama. ${ }^{28}$

Sob essa óptica, seria menos a "trama machadiana", e mais o discurso do narrador Aires que poria "em suspenso, e sob suspeita" a "fidelidade, a esperança, a transparência, a honestidade, a clareza, o amor". Conforme observado, é Aires quem sugere a relação entre o nome de Fidélia e o drama lírico de Beethoven, ensejando, assim, um cotejo entre a jovem viúva e a personagem da ópera, cotejo do qual a virtude de Fidélia sai inevitavelmente diminuída, à sombra da incansável Leonora; e é ele, também, quem transforma em ponto de honra, por meio da aposta com mana Rita, a manutenção do estado da viúva Noronha, algo com que a própria Fidélia jamais se comprometera. Aires, como narrador, induz o leitor a perscrutar o desejo de Fidélia, que prima pelo recato - como, aliás, Tristão -, enquanto é ele, Aires, como personagem, quem deseja constantemente, e uma leitura do romance atenta à dimensão do desejo facilmente deitaria por terra a máscara de urbanidade do diplomata e deixaria ver o homem de carne e osso, que luta incessantemente para sublimar o próprio erotismo.

Aires afere o respeito de Fidélia à memória de Noronha pelos cuidados que a viúva dedica à sepultura do marido e destila seu veneno, especulando se ela continuará com tais cuidados, casada com Tristão; ${ }^{29}$ enquanto é ele, Aires, quem deixou abandonada a sepultura da mulher, em Viena (vale lembrar que Fidélia se deu ao trabalho de mandar trasladar o corpo de Eduardo de Lisboa para o Rio de Janeiro, a fim de tê-lo perto de si, operação a que jamais se dedicou Aires, a despeito da facilidade que o cargo lhe propor-

\footnotetext{
28. Monteiro também reconhece certo traço comum aos narradores machadianos de 1900 e 1908: "Poderíamos talvez dizer que, de Bentinho a Aires, os narradores são apostadores um pouco obcecados, e a narrativa é uma sorte de aposta contra o errático e o incognoscível que nos cerca. Mas uma das diferenças importantes entre o Dom Casmurro e o Memorial de Aires é o tom. Aires, afinal, não parece buscar o convencimento, ou o autoconvencimento. A fidelidade é o tema em questão, não a matériaprima de um pré-julgamento, como na história de Capitu" (Monteiro, Pedro Meira. "O futuro abolido: anotações sobre o tempo no Memorial de Aires", cit., p. 50). A partir de uma leitura cum grano salis da reflexão do crítico, procura-se aqui demonstrar que "Aires, afinal, não parece buscar o convencimento, ou o autoconvencimento" - apenas não parece; porque, de fato, o busca.

29. Memorial de Aires, 30 jun. 1889.
} 
cionaria). Aires, logo que conhece Tristão, nota no rapaz "muita compostura e alguma dissimulação", ${ }^{\circ}$ e, não sem uma nota de julgamento de caráter, conjectura, repetidas vezes, sobre o quanto o "filho postiço" haveria omitido aos Aguiares acerca de seus planos; enquanto é ele, Aires, quem confessa frequentemente dissimular seu tédio e sua curiosidade e que louva a própria habilidade de calar. Por fim, Aires também põe em xeque a (por falta de melhor expressão) fidelidade filial de Tristão e Fidélia, quando estes seguem para Lisboa, supostamente abandonando os Aguiares; enquanto é ele quem, constrangido, recua pé ante pé, quando, "ao fundo, à entrada do saguão, [dá] com os dois velhos sentados, olhando um para o outro". ${ }^{31}$ Uma a uma, todas as faltas que Aires aponta em Tristão e Fidélia, é nele mesmo que se encontram. Quando diz que "esta Fidélia foge a alguma coisa, se não foge a si mesma", é de si mesmo que Aires fala, e talvez seja para fugir de si mesmo que ele transforma Tristão, Fidélia, Aguiar e Carmo nos protagonistas de uma narrativa que tem lugar, entre todos os lugares possíveis, no seu diário íntimo.

Cabe aqui um segundo alerta metodológico, desta vez feito por Marta de Senna. Em sua leitura do Dom Casmurro, a pesquisadora conclui que "o narrador cita repetidamente Otelo; o autor nos convida a pensar em Hamlet". As reiteradas evocações do Otelo seriam "pistas falsas" e fariam parte das "estratégias de embuste" de um narrador ardiloso, por meio das quais ele procuraria convencer o leitor da culpa de Capitu. A articulação deste alerta ao primeiro, o de Gledson - de que é necessário tratar o narrador do Memorial de Aires como o do Dom Casmurro -, tem como resultado a desconfiança de que também Tristan e Fidelio sejam pistas falsas, plantadas por um narrador tão inteligente quanto manipulador. Levando às últimas consequências essa proposta de leitura e parafraseando Senna, pode-se dizer: no Memorial de Aires, o narrador cita repetidamente Tristan e Fidelio; o autor nos convida a pensar em Lohengrin e Tannhäuser. Se aquelas óperas são requisitadas pelo narrador e fornecem as lentes pelas quais ele enxerga e dá a ver Tristão e Fidélia, estas subjazem à própria constituição do narrador.

Os diálogos intertextuais presentes no Memorial de Aires revelam-se sempre mais complexos, quando se tem em mente que o diplomata Marcondes Aires teve acesso em primeira mão a uma série de obras às quais o funcionário Machado de Assis teve acesso apenas em segunda mão. Caso evidente é o do Tristan, que o escritor pode conhecer por meio de artigos de jornal, de resenhas em revistas, de conversas com

30. Memorial de Aires, 22 set. 1888.

31. Memorial de Aires, sem data (última entrada). 
amigos, de partituras e de adaptações, ao passo que a personagem pode tê-lo aplaudido "até romperem as luvas", ${ }^{22}$ nas melhores casas de ópera da Europa. O Fidelio, embora fosse bastante conhecido pelo público fluminense oitocentista, também não fazia parte do repertório das companhias líricas do Rio de Janeiro do Segundo Reinado; já na Europa, era um título recorrente na programação das principais casas de ópera. ${ }^{33}$ Ora, a ópera é uma arte performática, que existe apenas no espaço e pelo tempo em que está sendo executada; faz mais sentido, portanto, que Aires tenha com esses dois títulos a intimidade necessária para mobilizá-los em seu discurso, do que Machado os utilize como matéria-prima para sua criação. Por outro lado, Machado teve oportunidade de assistir a Lohengrin e Tannhäuser, de ter a experiência desses dois títulos como óperas, e não como notícias de óperas; enfim, de estabelecer uma relação de fruição e diálogo com essas obras de arte.

A ação tanto do Tannhäuser quanto do Lohengrin ocorre na Alta Idade Média, na Turíngia e na Antuérpia, respectivamente, e tem como pano de fundo as Cruzadas. A primeira estreou em Dresden, em 1845, e conta a história do cavaleiro-trovador Heinrich, o Tannhäuser, que em meio às suas andanças e aventuras acaba docemente aprisionado no refúgio de Vênus, no interior do monte Wartburg. Apesar dos encantos da deusa, depois de um ano Heinrich anseia por retornar ao convívio dos mortais; clama pela Virgem Maria e vê-se subitamente transportado para o exterior desolado do monte. Segue um grupo que retorna de uma caça e vai dar no castelo do landgrave da Turíngia, onde em tempos passados ele próprio vencera diversos torneios de trovadores e onde vive Elisabeth, a sobrinha do landgrave, por quem era (e descobre ainda ser) apaixonado. Animado pela presença de Heinrich, o anfitrião oferece a mão da sobri-

\footnotetext{
32. A expressão é utilizada pelo narrador machadiano no capítulo II de A mão e a luva.

33. Não há registro, na imprensa fluminense, de montagens integrais do Fidelio no Rio de Janeiro, entre as décadas de 1840 e 1880 . Passagens sinfônicas e árias isoladas da ópera de Beethoven eram comuns em concertos e em récitas "de programa”, ou seja, em que eram oferecidos ao público trechos de diversas óperas, em vez de uma ópera única e íntegra. A razão para isso é que tanto as companhias líricas que visitavam a cidade quanto o público fluminense davam preferência aos repertórios italiano e francês, ou então a novidades do repertório alemão, e o Fidelio não se encaixava em qualquer dessas categorias. Quanto ao circuito europeu, basta que se leia o seguinte trecho do artigo "A música na Alemanha, II", de Artur Napoleão e Leopoldo Miguez: "Em seis meses, nos principais teatros de Viena, Dresden, Berlim e Munique, vinte e cinco ou trinta obras diversas se sucedem, produções de todas as épocas e todas as escolas" (Revista Musical e de Belas Artes, Rio de Janeiro, ano 1, n. 19, 10 maio 1879, p. 6).
} 
nha como prêmio do torneio que está por se iniciar: um a um, os demais trovadores entoam louvores ao amor virtuoso e à beleza de Elisabeth; no entanto, chegada a vez de Heinrich, a lembrança do convívio com a deusa pagã o domina, e ele compõe, lascivo, uma ode ao prazer fugaz. Todos no salão ficam horrorizados, e os demais cavaleiros fazem gesto de bater-se com o Tannhäuser, quando Elisabeth interpõe-se e pede que ele seja desculpado; arrependido e humilhado, Heinrich, com a anuência do landgrave, parte em peregrinação a Roma, em busca do perdão do papa. Durante toda a ausência de Heinrich, Elisabeth ora pela sua absolvição; contudo, quando ele retorna, é com a notícia de que o papa rejeitou seu pedido, vaticinando que os seus pecados seriam redimidos apenas quando de seu bastão de peregrino brotassem flores; Heinrich deixa o castelo, decidido a entregar-se definitivamente a Vênus, quando vê sair desse mesmo lugar um cortejo fúnebre, trazendo o corpo exânime de Elisabeth; o cavaleiro-trovador cai aos pés da amada e expira; nesse momento, os peregrinos erguem seus bastões, de onde começam a brotar flores, sinal divino de que seus pecados haviam sido redimidos pelo sacrifício de Elisabeth.

A segunda ópera mencionada estreou em Weimar, em 1850, e sua ação tem início quando o rei Henrique I, da Alemanha, chega à Antuérpia, a fim de reunir homens, para fazer frente às investidas húngaras sobre o seu território. Contudo, o rei tem primeiro de arbitrar uma disputa interna do ducado de Brabante: morto o duque, seu filho e herdeiro, Godfrey, desaparece misteriosamente na floresta, e a irmã dele, Elsa, próxima na linha de sucessão, é acusada de tê-lo assassinado; por isso, o conde Frederico de Telramund, apoiado por sua mulher, Ortrud, filha do príncipe de Friesland, reivindica o trono. $\mathrm{O}$ rei determina que a questão seja resolvida por meio de um combate corpo a corpo, desde que algum cavaleiro se voluntarie para defender a honra de Elsa; ninguém se apresenta, embora Elsa declare ter tido uma visão, em que um cavaleiro prateado surgia para defendê-la. No último instante, antes de o rei declará-la culpada, por não haver quem a defenda, desponta no rio um barco puxado por um cisne, trazendo um cavaleiro de armadura reluzente. $\mathrm{O}$ cavaleiro declara-se disposto a defender a donzela, desde que ela aceite casar-se com ele e que nunca lhe pergunte seu nome e origem, porque, caso ela o faça, ele será obrigado a partir definitivamente. Elsa aceita essas condições, o cavaleiro vence o combate, e os dois tornam-se duquesa e duque de Brabante. A insidiosa Ortrud, contudo, mantém-se próxima a Elsa e começa a inculcar, na moça, dúvidas a respeito do seu misterioso defensor; com o tempo, a jovem acaba não resistindo à curiosidade e faz a ele a pergunta interdita. O herói revela, então, ser Lohengrin, filho de Parsifal, guardião do Santo Graal, e que vem do castelo de Montsalvat, onde seu pai é rei, e ele, 
cavaleiro; em razão de um voto de humildade, os cavaleiros do Graal devem manter-se anônimos, e, uma vez revelada sua identidade em determinado lugar, é preciso que eles o deixem. Quando Lohengrin está prestes a partir, Ortrud confessa que enfeitiçou Godfrey e o transformou em um cisne, o mesmo que está atado ao barco do cavaleiro; Lohengrin usa seus poderes para desfazer o feitiço, e uma pomba desce dos céus à frente de outro barco, para levá-lo embora, ao mesmo tempo que Elsa expira nos braços do irmão devolvido à forma humana.

Lohengrin e Tannhäuser são cavaleiros errantes, enviados em ministério aos quatro cantos da Cristandade: Lohengrin pertence à ordem do Santo Graal e tem como tarefa defender donzelas injustamente acusadas; já quanto ao Tannhäuser, não se sabe a que ordem ele pertence, nem se pertence a alguma, porém é um cavaleiro, bateu-se em armas por seu suserano, perdeu-se em terras distantes e, por fim, tomou o hábito de peregrino, indo a Roma cumprir penitência. No centro do enredo das duas óperas está a viagem - e a busca por um porto seguro, simbolizado pela amada. Lohengrin e Tannhäuser dariam fim às suas errâncias e descansariam seus corpos no regaço de Elsa e Elisabeth, não fossem as intromissões de Ortrud e Vênus - ambas, note-se, figuras pagãs, representantes de uma ordem arcaica. Não é, igualmente, do retorno de uma longa jornada e da esperança de encontrar abrigo nos braços de uma companheira que trata o último romance de Machado de Assis? Se o repertório lírico contribuiu para a composição do narrador-personagem de Memorial de Aires - o diplomata aposentado, cansado de tanta viagem, espécie de cruzado moderno, de trovador da intimidade, melancólico e enamorado -, foi antes por meio de Tannhäuser e de Lohengrin do que de qualquer outra ópera.

Assinale-se que o núcleo dramático do Tannhäuser é o episódio do torneio dos trovadores, conforme indica o título completo da ópera: Tannhäuser und der Sängerkrieg auf Wartburg [Tannhäuser e o torneio de trovadores de Wartburg]. Ao fazer os cantores de sua ópera representarem os cantores do torneio, Wagner instala a metalinguagem no coração da ópera; salvo engano, a única outra ocasião em que faria algo semelhante seria em Die Meistersinger von Nürnberg. O episódio do torneio, além de chamar atenção para a fatura da representação - ao duplicá-la, internamente -, explicita a sua motivação: os cantores cantam porque aquele que for eleito o melhor cantor terá como prêmio a mão de Elisabeth. As analogias com o Memorial são evidentes: também ele expõe a fatura e a motivação da escrita do conselheiro. Quanto à fatura, se desde o início da década de 1880 a ficção machadiana demonstra alto grau de autoconsciência narrativa, no Memorial ela exibe, igualmente, uma profunda autoconsciência escritural, dado 
que o livro de 1908 possui um narrador que não apenas controla o processo narrativo, como também comanda a situação escritural, reencenando-a à perfeição, por meio da forma "diário" - que Antonio Candido descreve como uma "técnica progressiva", por meio da qual, "disfarçando a onisciência do romancista, o narrador ignora em teoria o que se passará na entrada seguinte". ${ }^{34}$ Quanto à motivação, o que leva o conselheiro a escrever é o mesmo que leva os trovadores do Tannhäuser a cantar: o desejo. Repisando o que diz Monteiro, cumpre observar que, no Memorial,

como em outros momentos da narrativa machadiana, a escrita é a compensação da impossibilidade de realização do narrador. $\mathrm{O}$ foco narrativo se estabelece a partir de uma incapacidade. No caso do conselheiro Aires, a aposta é a realização compensatória do desejo que ele sente pela viúva, desde o início. Já a narrativa mesma é a posta em cena daquele desejo, como se a ficção servisse a compensar uma perda, que é a perda do objeto querido. ${ }^{35}$

À sensualidade de Tannhäuser opõe-se a espiritualidade de Lohengrin: um dedica versos obscenos àquela cuja mão almeja, o outro tem como missão salvar donzelas inocentes; um possui a experiência do prazer terreno, ganha com Vênus em Wartburg, o outro tem $o$ conhecimento do êxtase divino, aprendido com o Graal em Montsalvat; um é assombrado pelo fantasma da perdição, o outro, pela fantasia da salvação. Aires combina-os ambos, vestindo a máscara de Lohengrin por sobre a face de Tannhäuser: exteriormente, é um senhor cortês, já despido de toda libido e de toda vaidade; interiormente, é um homem atormentado, que luta para sofrear seus desejos e mal disfarça sua imodéstia. ${ }^{36}$

Cumpre retornar, agora, à proposição seminal, feita por Antonio Candido, da forma "diário", no Memorial de Aires, como uma "técnica progressiva". Por meio dela, é como se o leitor pudesse flagrar o autor (do diário, bem entendido) no ato da escrita,

34. CANDIDO, Antonio. Op. cit., p. 27.

35. monteiro, Pedro Meira. "Oui, mais il faut parier: fidelidade e dúvida no Memorial de Aires", cit., p. 313. 36. A bem da verdade, o dilema entre o carnal e o espiritual encontra-se já no interior da trama do Tannhäuser. Lawrence Kramer considera esse embate interno da personagem o eixo central da ópera (Kramer, Lawrence. "Wagner's Gold Standard: Tannhäuser and the General Equivalent”. Cambridge Opera Journal, 21.2, New York, Cambridge University Press, 2010, pp. 142-3). A celebração de uma redenção impossível também não é algo estranho ao leitor do Memorial de Aires, conforme apontam, enfática e insistentemente, os ensaios de Pedro Meira Monteiro sobre o romance. 
como se pudesse ler por sobre os seus ombros, enquanto ele escreve; em outras palavras, como se assistisse à sua performance escritural. A forma "diário" é performativa por natureza: nela, a progressão temporal ocorre antes no plano da narração do que no da narrativa; antes na enunciação do discurso, do que no discurso enunciado. Essa ênfase no presente, renovado a cada entrada do Memorial, tem como efeito o enfraquecimento do eixo paradigmático e o fortalecimento do eixo sintagmático, aproximando o romance das artes que se desenvolvem eminentemente no tempo, em oposição àquelas que se desenvolvem principalmente no espaço - mais distante da pintura, mais perto da música. Assim, já na escolha pela forma diário, antes mesmo do estabelecimento dos diálogos intertextuais, revela-se a ascendência da música sobre a composição do último romance de Machado de Assis.

Outro traço que acerca o Memorial de Aires do registro musical é o esgarçamento do seu enredo, apontado desde as primeiras críticas do romance. Barreto Filho, na década de 1960, resume a percepção a respeito da obra predominante ao longo do século xx: "O livro já não tem mais enredo, é uma pura música interior fluindo velada de sua saudade e de seu espírito e deixando que a bondade e a simpatia humana se desenvolvam francamente". ${ }^{37}$ Já no século XXI, e desde uma perspectiva histórica, Hans Ulrich Gumbrecht enxerga na última narrativa do Bruxo do Cosme Velho uma "modernidade flaubertiana": "Neste ponto, o autor ficcional de Memorial de Aires encontra-se com o verdadeiro escritor Flaubert, que, na sua correspondência com a amada, cunhou a famosa expressão 'um livro sobre nada' - um livro que não dependeria nem de intriga, nem sequer de referência com a realidade". ${ }^{8}$ Monteiro, por sua vez, sublinha que a "força narrativa de Machado de Assis ganha muito quando atentamos para a maneira como seus referentes - as coisas de que se fala - são diluídos numa espécie de horizonte borrado". ${ }^{39}$ Para esse autor, tal diluição não seria sinal de um abrandamento do espírito inquiridor e corrosivo do escritor, nem de um arrefecimento da sua força criativa, e sim de uma ruptura com o paradigma da representação:

\footnotetext{
37. Barreto filho, José. “O romancista”. In: assis, Machado de. Obra completa. 3 vols. Org. Afrânio Coutinho. Rio de Janeiro: Aguilar, 1962, vol. 1, p. 111.

38. Gumbrecht, Hans Ulrich. Atmosfera, ambiência, Stimmung: sobre o potencial oculto da literatura. Tradução de Ana Isabel Soares. Rio de Janeiro: Contraponto; Editora PUC-Rio, 2014, p. 113. 39. Monteiro, Pedro Meira. "O outono da escrita: as últimas páginas de Machado de Assis e a promessa não cumprida do Brasil”, cit., p. 227.
} 
O referente da escrita, como o referente do desejo do narrador, se esvai a cada momento em que o escritor crê acercar-se dele. Portanto, a representação não se sustenta mais na fidelidade a um mundo exterior ao próprio ato de escrever. Ao contrário, é pela escrita que eu me aproximo do objeto, embora o que eu escreva não sirva senão como rastro, ou o testemunho de um desejo irrealizado de aproximação a que a ficção dá forma. O resultado do que se escreve é fiel, portanto, tão somente ao narrador, cuja voz recompõe um mundo que é, ao fim, apenas uma construção compensatória, isto é, nem mais nem menos que a própria escrita. ${ }^{\circ}$

O que a ópera - ou a contraópera que é a narrativa machadiana - pode revelar é, justamente, a crise da referência. Deslanchada a obra, não há mais matéria de representação, neste momento em que a literatura revela-se não como documento, mas como acontecimento. ${ }^{41}$

Quanto mais a obra literária se volta sobre os seus próprios referentes internos, em detrimento dos externos, quanto mais ela se afasta de um regime representacional, mais se aproxima da abstração; mais se aproxima, portanto, da música, considerada na estética clássica a mais nobre entre as artes, justamente porque a menos motivada, a menos dependente de qualquer elemento exterior a ela mesma.

Não por acaso, Gumbrecht conclui sua leitura do Memorial retomando um conceito que desenvolve em outro texto, de caráter eminentemente teórico, a partir de uma passagem de Heidegger. Trata-se do conceito de Stimmung, cujo significado é o de "atmosfera", ou "afinação" (a raiz de Stimmung é Stimme, "voz"), e que diz respeito a um conjunto de informações estéticas que evocam e recriam determinada sensação, determinado clima - que pode ser historicamente localizado (a decadência fin-de-siècle, na Morte em Veneza de Thomas Mann, por exemplo) ou não ("medo", "raiva", "esperança", "alegria", "entusiasmo", "serenidade", "tédio"). Gumbrecht intitula o artigo em que desenvolve o conceito de Stimmung de "Reading for the Stimmung?" [Lendo pela afinação?], em claro contraponto ao célebre ensaio de Peter Brooks, "Reading for the Plot" [Lendo pelo enredo], propondo, assim, em relação às narrativas nas quais o enredo já não é o elemento central, uma leitura das sensações evocadas, do clima recriado - ou, dito de outra forma, uma escuta da afinação, quando o que importa já não é a melodia, uma contemplação da paisagem sonora, quando o horizonte visível é puro esfumado.

40. Idem. "Oui, mais il faut parier: fidelidade e dúvida no Memorial de Aires", cit., p. 314 41. Idem. "O futuro abolido: anotações sobre o tempo no Memorial de Aires", cit., p. 50. 
Ainda que haja interesse no plot do Memorial de Aires, é no seu Stimmung que reside a sua maior riqueza, o seu lirismo melancólico, o mesmo que emana do Tannhäuser e, em menor grau, do Lohengrin. Ainda que haja pontos de contato entre os enredos do romance machadiano e da ópera wagneriana - conforme se buscou demonstrar aqui -, é principalmente por meio da afinação comum, da atmosfera semelhante, que essas obras se irmanam. Foi, portanto, resgatando sua memória musical e sobrepondo a sensação ao sentido - ou, dito de outro modo, compondo a música, antes do drama -, que Machado de Assis estabeleceu o diálogo mais fino entre a literatura e as demais artes de que se tem notícia em sua obra, no seu romance derradeiro.

Marcelo da Rocha Lima Diego é doutor em Espanhol e Português pela Universidade de Princeton. 